\title{
Vanadate-induced nitric oxide production: role in osteoblast growth and differentiation
}

\author{
Ana M. Cortizo a, *, Mariana Caporossi a , Gabriela Lettieri a , Susana B. Etcheverry a,b \\ ${ }^{a}$ Cátedra de Bioquímica Patológica, Facultad de Ciencias Exactas, Universidad Nacional de La Plata, 47 y 115 (1900) La Plata, Argentina \\ ${ }^{\mathrm{b}}$ CEQUINOR, Facultad de Ciencias Exactas, Universidad Nacional de La Plata, 47 y 115 (1900) La Plata, Argentina
}

Received 10 January 2000; received in revised form 3 May 2000; accepted 5 May 2000

\begin{abstract}
Nitric oxide (NO) has been shown to act as a mediator of cytokines in bone tissue. We have previously demonstrated that vanadium compounds are insulin- and growth factor-mimetic compounds in osteoblasts in culture, although high doses are toxic to these cells. In this study, we measured NO production in two osteoblast-like cells (UMR106 and MC3T3E1) incubated with different concentrations $(2.5-100 \mu \mathrm{M})$ of vanadate. Vanadate induced NO release in a biphasic manner, with levels being significantly increased at concentrations over $50 \mu \mathrm{M}$. The NO donor, sodium nitroprusside, mimicked the vanadate effect: it inhibited cell growth and alkaline phosphatase activity in a dose-dependent manner. Vanadate enhanced the NO synthases, the endothelial and inducible (eNOS and iNOS) isoforms, in a dose-dependent manner. Experiments performed with the ionophore A23187 and EGTA suggested that vanadate-induced NO production involves $\mathrm{Ca}^{2+}$-dependent and -independent mechanisms. Altogether, our results suggest that NO may play a critical role in the bioactivity of vanadium in osteoblast-like cells. (C) 2000 Elsevier Science B.V. All rights reserved.
\end{abstract}

Keywords: Nitric oxide (NO); Nitric oxide (NO) synthases; Vanadium; Growth; Osteoblast differentiation; Bone; Cytotoxicity

\section{Introduction}

Vanadium is a transition element which exists in trace amounts in foods (Nriagu, 1998). Once incorporated into the organism, vanadium is mainly stored in bone and kidney (Etcheverry and Cortizo, 1998). Almost 20 years ago, it was discovered that vanadate exhibits insulinmimetic actions, being hypoglycemic in animal models of diabetes and in types 1 and 2 diabetic patients (Shechter, 1990). Actually, clinical trials are in progress in order to assess the therapeutic application of vanadium(IV) in the treatment of this disease (Goldfine et al., 1995; Cohen et al., 1995; Halberstam et al., 1996; Cusi et al., 1997).

However, some toxic effects after the chronic use of these agents have also been reported (Domingo, 1996; Sabbioni et al., 1993). Using a model of osteoblast-like cells in culture, we have previously described that compounds of vanadium(IV) and (V) act, at low concentrations, as insulin and growth factor mimetics (Cortizo and

\footnotetext{
* Corresponding author. Tel.: +54-221-210784; fax: +54-2214530189.

E-mail address: cortizo@nahuel.biol.unlp.edu.ar (A.M. Cortizo).
}

Etcheverry, 1995; Etcheverry et al., 1997; Barrio et al., 1997; Sálice et al., 1999). Nevertheless, high concentrations of different vanadium derivatives induce inhibition of growth, osteoblast differentiation and morphological transformation of osteoblasts in culture. Most evidence points toward the ability of vanadium compounds to enhance the phosphorylation of protein tyrosine (Gresser and Tracey, 1990). Consequently, an increase in phosphotyrosine protein levels could transduce vanadium signaling, leading to its biological effects. However, additional mechanisms may participate in the action of vanadium in bone.

Recently, the importance of nitric oxide (NO) as a signaling molecule involved in bone turnover, both in vivo and in vitro, has been reported (Ralston, 1997; Danziger et al., 1997; Van't Hof and Ralston, 1997; Damoulis and Hauschka, 1997; McCarthy et al., 1997; Hikiji et al., 1997; Chae et al., 1997). NO acts as a mediator of several stimuli, such as cytokines, mechanical stretch and sexual hormones in bone cells. It has also been suggested that NO exerts biphasic effects on bone-related cells: high concentrations inhibit osteoclast-mediated bone resorption, as well as the growth and differentiation of osteoblasts, and low concentrations potentiate cytokine-induced bone resorption 
and may regulate normal osteoblast growth. In addition, immunohistochemistry and reverse transcription polymerase chain reaction ( $\mathrm{RT} / \mathrm{PCR}$ ) experiments indicate that mainly endothelial (eNOS) and inducible NO synthases (iNOS) are expressed in osteoblast-like cells (Ralston et al., 1994; Helfrich et al., 1997; Armour and Ralston, 1998; Fox and Chow, 1998; Togari et al., 1998; Hukkanen et al., 1999).

The purpose of the present study was to examine whether (1) vanadate regulates NO release into culture medium, (2) NO actively affects osteoblast growth and differentiation, using alkaline phosphatase activity as a marker, and (3) eNOS and iNOS protein expression is altered by vanadate in two osteoblast-like cells in culture.

\section{Material and methods}

\subsection{Materials}

Sodium orthovanadate (V) was obtained from Sigma. Tissue culture material was provided by Corning (Princeton, NJ). Dulbecco's Modified Eagles Medium (DMEM) and trypsin-EDTA were supplied by Gibco (Gaithersburg, MD) and fetal bovine serum was from Gen (Argentina). Polyclonal endothelial and inducible NO synthase (NOS) antibodies were from Research Biochemicals International (RBI; MA, USA). All other chemicals and reagents were obtained from commercial sources and were of analytical grade.

\subsection{Cell culture and incubations}

MC3T3E1 osteoblastic mouse calvaria-derived cells and UMR106 rat osteosarcoma-derived cells were grown in $75-\mathrm{cm}^{2}$ flasks at $37^{\circ} \mathrm{C}$ in a humidified $5 \% \mathrm{CO}_{2}$ atmosphere in DMEM supplemented with $100 \mathrm{U} / \mathrm{ml}$ penicillin, $100 \mu \mathrm{g} / \mathrm{ml}$ streptomycin and $10 \%(\mathrm{v} / \mathrm{v})$ fetal bovine serum. When $70-80 \%$ confluence was reached, cells were subcultured using $0.1 \%$ trypsin $-1 \mathrm{mM}$ EDTA in $\mathrm{Ca}^{+2}$ - $\mathrm{Mg}^{+2}$-free phosphate-buffered saline (PBS) (Cortizo and Etcheverry, 1995; Etcheverry et al., 1997). For experiments, cells were seeded in six- or twenty-four-well plates at a density of $2.5 \times 10^{4}$ cells $/$ well. When cells reached confluence, the medium was replaced with serum- and phenol red-free DMEM and cells were incubated with different concentrations of vanadate or medium alone (basal condition), with or without other agents (EGTA, A23187) for $24 \mathrm{~h}$. At the end of this incubation period, the culture medium was collected, cells were removed by centrifugation, and the nitrite level was evaluated as described below. The cell monolayer was washed with PBS and extracted with $0.1 \%$ Triton-X100. The cell protein content was assayed by the Bradford method (Bradford, 1976). Osteoblast differentiation was assessed by measuring alkaline phosphatase activity as a marker of the osteoblast phenotype (Stein and Lian, 1993), as previously described (Cortizo and Etcheverry, 1995). Briefly, the enzyme activity was assayed by the hydrolysis of $p$-nitrophenyl phosphate to $p$-nitrophenol at $37^{\circ} \mathrm{C}$ in glycine buffer $\mathrm{pH} 10.5$ and absorbance at $405 \mathrm{~nm}$ was measured.

In another series of experiments, cells were incubated with different concentrations of the NO donor sodium nitroprusside, and cell proliferation and alkaline phosphatase activity were evaluated. Alternatively, cells were lysed in Laemmli buffer under reducing conditions (Laemmli, 1970), in order to evaluate NOS protein by Western blot as described below.

\subsection{Cell proliferation. Crystal violet bioassay}

The growth of osteoblast-like cells was determined by the crystal violet bioassay (Okajima et al., 1992). Briefly, cells were washed with PBS and fixed with 5\% glutaraldehyde for $10 \mathrm{~min}$. Then, they were stained with $0.5 \%$ crystal violet $/ 25 \%$ methanol for $10 \mathrm{~min}$. After that, the excess dye was discarded and the plate was washed with water and dried. The dye taken up by the viable cells was extracted using $0.1 \mathrm{M}$ glycine $/ \mathrm{HCl}$ buffer, $\mathrm{pH} 3.0 / 30 \%$ methanol and transferred to test tubes. Absorbance was read at $540 \mathrm{~nm}$ after a convenient dilution. We have previously shown that, under these conditions, the colorimetric bioassay results strongly correlate with the number of viable cells measured by cell counting after staining with Trypan blue in a Neubauer chamber $(r=0.90, P<$ $0.001 ; r=0.97, P<0.001$; for UMR and MC3T3E1 cells, respectively; Cortizo and Etcheverry, 1995; Sálice et al., 1999).

\subsection{NO production}

NO production was assessed by measuring the stable end product of NO, nitrite, in the culture medium using the Griess reaction (Green and Wagner, 1982). Briefly, 400- $\mu 1$ samples of conditioned media or nitrite standards $(0-100$ $\mu \mathrm{M})$ were mixed with $400 \mu \mathrm{l}$ of Griess reagent $(1 \%$ sulfanilamide and $0.1 \%$ naphthylethylene-diamine in $5 \%$ phosphoric acid), and absorbance was measured at $530 \mathrm{~nm}$ against a blank prepared with non-conditioned medium.

\subsection{Western blot analysis of NOS protein}

The protein content in the cell lysates was evaluated by the method of Lowry et al. (1951). The lysate was heated at $100^{\circ} \mathrm{C}$ for $3 \mathrm{~min}$ and $15 \mu \mathrm{g}$ of protein was subjected to $8 \%$ sodium dodecyl sulfate polyacrylamide gel electrophoresis. The separated proteins were then transferred to nitrocellulose membranes. To control loading and transfer, the membranes were reversibly stained with $0.2 \%$ Ponceau $\mathrm{S}$ in 3\% trichloroacetic acid before blocking (Docena et al., 1999). After washing with water, the membranes were blocked in 3\% non-fat dry milk in Tris-buffered saline 
(TBS) for $2 \mathrm{~h}$ at room temperature and incubated with anti-iNOS or eNOS polyclonal antibodies in $0.5 \%$ bovine serum albumin in PBS $(1: 2000)$ at $4^{\circ} \mathrm{C}$ for $24 \mathrm{~h}$. After four washes with TBS, the membranes were incubated with a secondary goat anti-rabbit antibody, followed by staining with the avidin/alkaline phosphatase-biotin reagent and nitroblue tetrazolium - 5-bromo-4-chloro-3-indolyl phosphate (NBT-BCIP) from the Vectastin kit. The intensity of the iNOS or eNOS specific bands was quantified by densitometry after scanning of nitrocellulose paper using a Hewlett-Packard Scanjet 4C and images were analyzed using the Scion-beta 2 program.

\subsection{Statistical analysis}

Studenst's $t$-test was used for comparisons between basal and experimental groups. All results are expressed as means \pm S.E.M. and represent at least three different experiments.

\section{Results}

\subsection{Effect of vanadate on osteoblast growth and differenti- ation}

As we have previously described, vanadate regulated osteoblast growth in a biphasic manner (Etcheverry and Cortizo, 1998). It stimulated cell proliferation at $2.5 \mu \mathrm{M}$ in MC3T3E1 and 2.5-50 $\mu \mathrm{M}$ in UMR106 cells, but inhibited cell growth at higher concentrations (Table 1). The greatest vanadate-induced inhibition of cell growth was observed with the MC3T3E1 non-transformed osteoblast-like cells, which suggests a great sensitivity of this cell line to vanadate. In addition, vanadate inhibited osteoblast differentiation in a dose-related manner, as evaluated by the alkaline phosphatase specific activity in the UMR106 cells,

Table 1

Effects of vanadate on osteoblast-like cell proliferation and differentiation

\begin{tabular}{cccc}
\hline $\begin{array}{l}\text { Vanadate } \\
(\mu \mathrm{M})\end{array}$ & $\begin{array}{l}\text { MC3T3E1 } \\
\text { cell number } \\
(\% \text { basal) }\end{array}$ & $\begin{array}{l}\text { UMR106 } \\
\text { cell number } \\
(\% \text { basal })\end{array}$ & $\begin{array}{l}\text { Alkaline } \\
\text { phosphatase } \\
(\% \text { basal })\end{array}$ \\
\hline 0 & $100 \pm 3$ & $100 \pm 5$ & $100 \pm 6$ \\
2.5 & $119 \pm 4^{* *}$ & $105 \pm 4$ & $70 \pm 5^{* *}$ \\
10 & $75 \pm 5^{* * *}$ & $116 \pm 5^{*}$ & $57 \pm 9^{* * *}$ \\
25 & $62 \pm 6^{* * *}$ & $117 \pm 6^{*}$ & $42 \pm 5^{* * *}$ \\
50 & $54 \pm 1^{* * *}$ & $109 \pm 5$ & $41 \pm 7^{* * *}$ \\
100 & $33 \pm 6^{* * *}$ & $85 \pm 3^{*}$ & $43 \pm 11^{* * *}$ \\
\hline
\end{tabular}

Numbers are expressed as \% basal and represent means \pm S.E.M. $(n=9)$. Basal values are $1.3 \times 10^{4}$ cells $/ \mathrm{ml}(\mathrm{MC} 3 \mathrm{~T} 3 \mathrm{E} 1), 2.7 \times 10^{4} \mathrm{cells} / \mathrm{ml}$ (UMR106) for proliferation and $132 \mathrm{nmol} p$-nitrophenol $/ \mathrm{min} / \mathrm{mg}$ protein for alkaline phosphatase activity (UMR106 cells).

${ }^{*}$ Differences vs. basal $(0 \mu \mathrm{M}$ vanadate): $P<0.05$.

** Differences vs. basal $(0 \mu \mathrm{M}$ vanadate $): P<0.002$.

* * * Differences vs. basal ( $0 \mu \mathrm{M}$ vanadate): $P<0.001$.

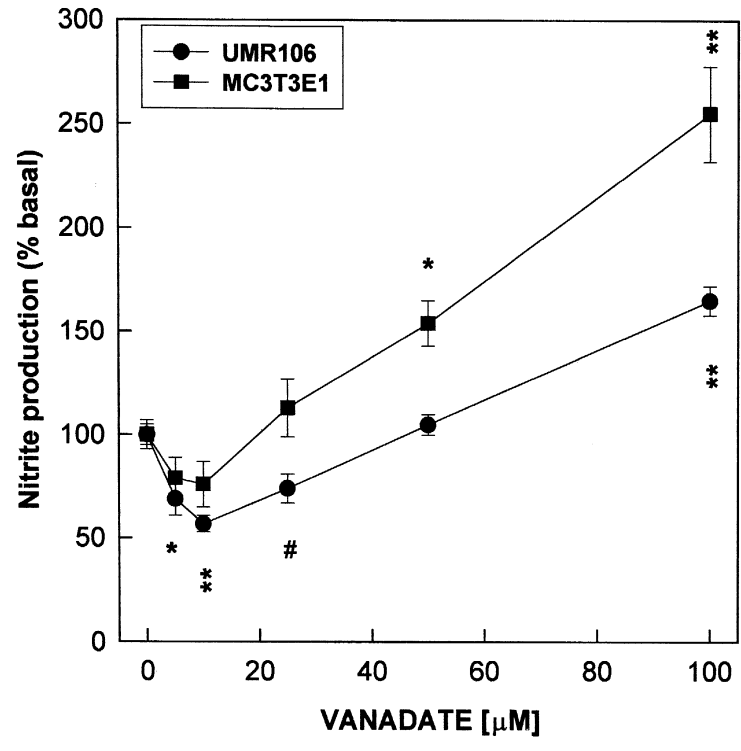

Fig. 1. Effect of vanadate on nitrite production by osteoblast-like cells. Cells were incubated for $24 \mathrm{~h}$ with different vanadate concentrations. The accumulation of $\mathrm{NO}$ was assayed by the Griess reaction and calculated as nmol nitrite/mg protein and is expressed as \% basal (without vanadate). Basal values are $6.8 \pm 0.5$ and $7.2 \pm 0.4 \mathrm{nmol} / \mathrm{mg}$ protein for MC3T3E1 and UMR106 cells, respectively. Values are means \pm S.E.M. $(n=8)$. Differences vs. basal are: ${ }^{\#} P<0.05,{ }^{*} P<0.01,{ }^{*}{ }^{*} P<0.001$.

the inhibition being statistically significant at $2.5 \mu \mathrm{M}$ (Table 1).

\subsection{Effect of vanadate on NO production by osteoblast-like cells}

UMR106 and MC3T3E1 cells were treated with different doses of vanadate for $24 \mathrm{~h}$ and the NO released into the culture medium was measured. Fig. 1 shows that vanadate caused NO production in a biphasic manner. At low concentrations (5 and $10 \mu \mathrm{M}$ for MC3T3E1 and 5-25 $\mu \mathrm{M}$ for UMR cells), a slight decrease was observed in both osteoblast lines, although it was only statistically significant in the case of the UMR106 cells. Increasing the vanadate concentration in the medium induced an increase in the NO production, which was statistically significant at $50-100 \mu \mathrm{M}$ for MC3T3E1 and $100 \mu \mathrm{M}$ for the UMR106 osteoblast-like cells. These results suggest that the highest amounts of NO are released in response to high concentrations of vanadate, in parallel with the vanadate-induced inhibition of cell growth. Fig. 1 also shows that the non-transformed MC3T3E1 cells were more sensitive to the vanadate-stimulated $\mathrm{NO}$ accumulation in the culture medium than were the osteosarcoma UMR106 cells.

\subsection{Effect of sodium nitroprusside on osteoblast growth and differentiation}

To investigate the direct effect of NO on osteoblast-like cell progression, we used sodium nitroprusside, an NO-re- 
leasing agent, with both osteoblast lines. Fig. 2A shows that sodium nitroprusside inhibited cell number in a doserelated manner. Apparent inhibition ( $K_{i}$ values) was 30 and $350 \mu \mathrm{M}$ for MC3T3E1 and UMR106 cells, respectively. The inhibitory action of sodium nitroprusside was stronger on the MC3T3E1 cells than on the UMR106 cells. In the latter, a slight but not significant stimulation of cell
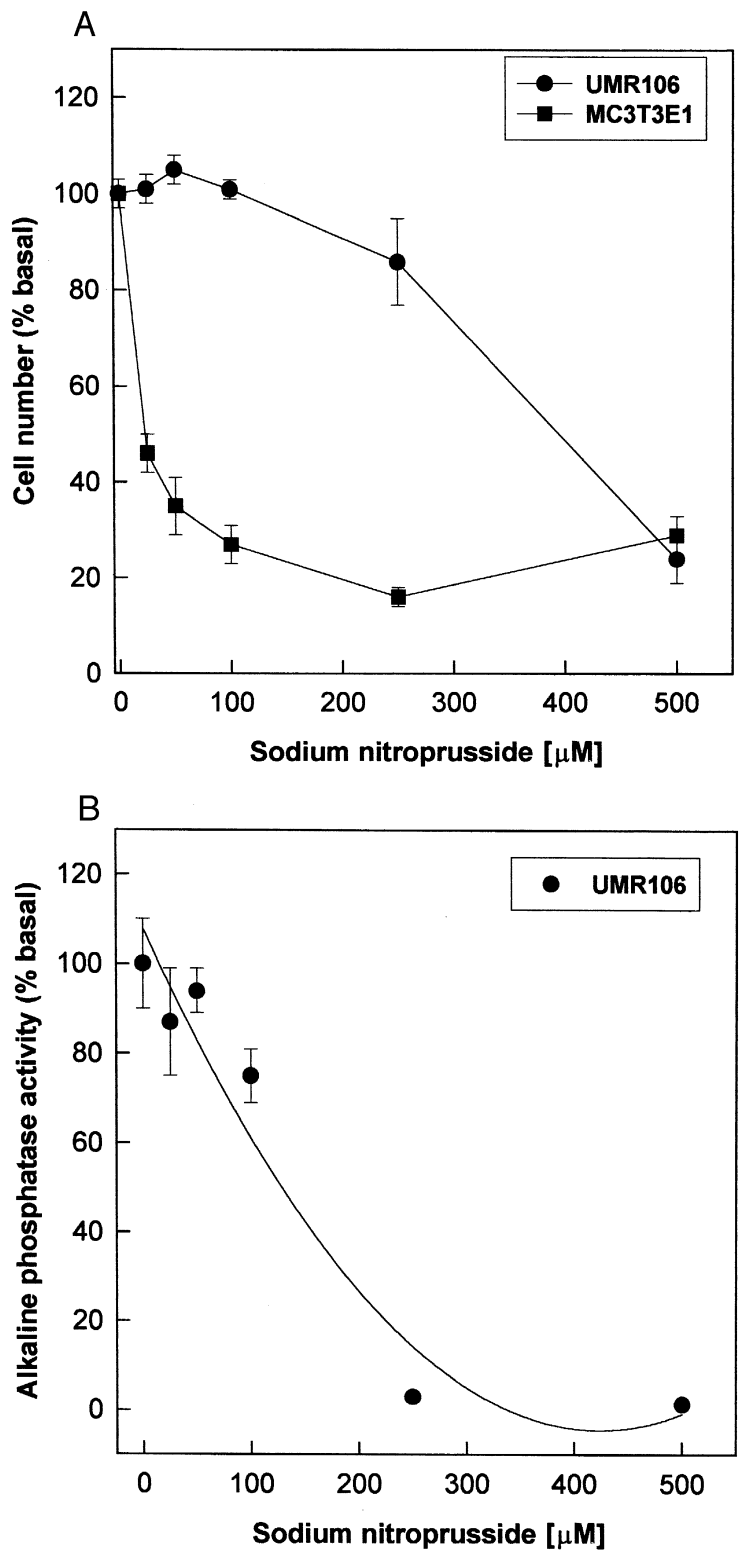

Fig. 2. (A) Effect of sodium nitroprusside on osteoblast proliferation. Cells were incubated in serum-free medium with different concentrations of sodium nitroprusside for $24 \mathrm{~h}$. Cell proliferation was evaluated by the crystal violet bioassay as described in Section 2 and expressed as \% basal (without vanadate). Basal values are $5.7 \pm 0.2 \times 10^{4}$ and $3.9 \pm 0.05 \times 10^{4}$ cell number/ml for MC3T3E1 and UMR106 cells, respectively. Values are means \pm S.E.M. $(n=8)$. (B) Effect of sodium nitroprusside on osteoblast differentiation. Cells were incubated with sodium nitroprusside at the doses indicated in the figure. Alkaline phosphatase activity was evaluated as a specific marker of osteoblast differentiation and is expressed as \% basal (without vanadate). Basal value is $160 \pm 33 \mathrm{nmol} / \mathrm{min}$ $\mathrm{mg}$ protein. Values are means \pm S.E.M. $(n=6)$.
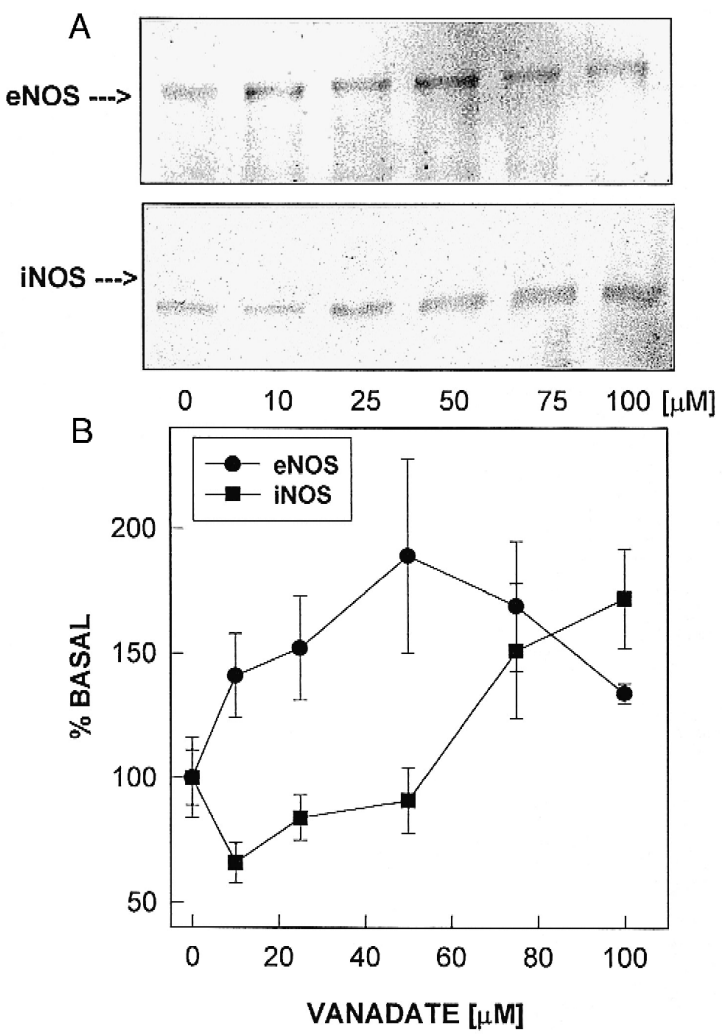

Fig. 3. Expression of NOS protein during the induction of NO by vanadate. MC3T3E1 osteoblast-like cells were treated with different doses of vanadate for $24 \mathrm{~h}$. Treated cells were lysed in Laemmli buffer and electrophoresed under reducing conditions on an $8 \%$ SDS-PAGE. (A) Western blot was assayed using specific rabbit polyclonal antibody against eNOS or iNOS. A representative blot from three independent experiments is presented. (B) Images were scanned and analyzed by the Scion-beta 2 program. The relative intensity of each band is presented as $\%$ basal condition (without vanadate) as a function of the vanadate concentration and represents the means \pm S.E.M. $(n=3)$.

growth was consistently observed at $50 \mu \mathrm{M}$ sodium nitroprusside. These results also suggest a stronger sensitivity of MC3T3E1 cells than UMR106 cells to NO-induced cell arrest.

In addition, the effect of $\mathrm{NO}$ on osteoblast differentiation was evaluated in the UMR106 cells by assaying alkaline phosphatase specific activity. It can be seen in the

Table 2

Effect of the $\mathrm{Ca}^{2+}$ ionophore A23187 on basal and vanadate-modulated NO production and MC3T3E1 osteoblast growth

\begin{tabular}{lcc}
\hline Treatment & $\begin{array}{l}\text { Cell number } \\
(\% \text { basal })\end{array}$ & $\begin{array}{l}\text { NO production } \\
(\% \text { basal })\end{array}$ \\
\hline Control & $100 \pm 2$ & $100 \pm 8$ \\
$+50 \mu$ M Vanadate & $50 \pm 2^{*}$ & $176 \pm 4^{*}$ \\
$+100 \mu$ M Vanadate & $44 \pm 1^{*}$ & $219 \pm 11^{*}$ \\
$1 \mu$ M A23187 & $56 \pm 4^{*}$ & $157 \pm 4^{*}$ \\
$+50 \mu$ M Vanadate & $8 \pm 0.6^{*}$ & $901 \pm 45^{*}$ \\
$+100 \mu$ M Vanadate & $8 \pm 0.4^{*}$ & $1180 \pm 90^{*}$ \\
\hline
\end{tabular}

Results are expressed as \% basal and represent the means \pm S.E.M. $(n=6)$. Basal values are $5.1 \times 10^{4}$ cells $/ \mathrm{ml}$ for osteoblast growth and $4.4 \mathrm{nmol}$ nitrite $/ \mathrm{mg}$ protein for NO production.

"Differences vs. control: $P<0.001$. 
Table 3

Effect of the calcium chelator EGTA on basal and vanadate-modulated NO production and UMR106 osteoblast growth

\begin{tabular}{lcl}
\hline Treatment & $\begin{array}{l}\text { Cell number } \\
\text { (\% basal) }\end{array}$ & $\begin{array}{l}\text { NO production } \\
\text { (\% basal) }\end{array}$ \\
\hline Control & $100 \pm 2$ & $100 \pm 2$ \\
$+75 \mu$ M Vanadate & $94 \pm 2$ & $125 \pm 3^{* *}$ \\
$+100 \mu$ M Vanadate & $81 \pm 5^{*}$ & $151 \pm 6^{* *}$ \\
1 mM EGTA & $100 \pm 2$ & $104 \pm 4$ \\
$+75 \mu$ M Vanadate & $92 \pm 1^{*}$ & $117 \pm 3^{*}$ \\
$+100 \mu$ M Vanadate & $80 \pm 3^{*}$ & $139 \pm 5^{* *}$ \\
\hline
\end{tabular}

Results are expressed as \% basal and represent the means \pm S.E.M. $(n=6)$. Basal values are $3.7 \times 10^{4}$ cells $/ \mathrm{ml}$ for osteoblast growth and $5.4 \mathrm{nmol}$ nitrite $/ \mathrm{mg}$ protein for $\mathrm{NO}$ production.

${ }^{*}$ Differences vs. control: $P<0.01$

${ }^{*}$ Differences vs. control: $P<0.001$.

Fig. 2B that sodium nitroprusside inhibited alkaline phosphatase activity in a concentration-dependent manner, with an apparent $K_{i}$ of $130 \mu \mathrm{M}$.

\subsection{Effect of vanadate on endothelial and inducible $N O$ synthase protein expression}

We performed Western blot analysis to further evaluate the effect of vanadate on the protein expression of the two major forms of NOS described in osteoblastic cells. Western blot with anti-endothelial NOS antibody revealed a band corresponding to a relative molecular mass of 135 $\mathrm{kDa}$ (Fig. 3A). This band was increased after incubation with $10-100 \mu \mathrm{M}$ vanadate in the culture medium of the MC3T3E1 cells (Fig. 3B). In addition, by using an anti-inducible NOS antibody, we could detect a protein (130 $\mathrm{kDa}$ ), whose expression was enhanced to some extent by $75-100 \mu \mathrm{M}$ vanadate (Fig. 3A and B). These results suggest that low concentrations of vanadate predominantly enhance eNOS expression, while doses over $75 \mu \mathrm{M}$ also stimulate the inducible form of NOS in osteoblasts in culture.

\subsection{Effect of altering extra- and intracellular $\mathrm{Ca}^{2+}$ levels on osteoblastic cells}

Experiments were performed to characterize the $\mathrm{Ca}^{2+}$ dependence of cellular NO production, under either basal or vanadate-stimulated conditions. To increase intracellular $\mathrm{Ca}^{2+}$ levels, the MC3T3E1 cells were exposed to the $\mathrm{Ca}^{2+}$ ionophore A23187. After a 24-h incubation with A23187 alone, an inhibition of cell growth was observed; this effect was in parallel with a $57 \%$ increase in NO production (Table 2). Moreover, A23187 significantly potentiated $(P<0.001)$ the vanadate-induced cytotoxicity and NO release (Table 2). A similar effect was observed when UMR106 osteosarcoma cells were cultured with $1 \mu \mathrm{M}$ A23187, under basal conditions or after vanadate incubation (data not shown).
The effect of sequestration of extracellular $\mathrm{Ca}^{2+}$ was investigated and the results are shown in Table 3 . In unstimulated UMR106 cells, $1 \mathrm{mM}$ EGTA did not affect cell growth or NO production, suggesting that most of the basal NO production was $\mathrm{Ca}^{2+}$ independent. However, the vanadate-induced NO production, but not the cytotoxicity, was partially blocked after EGTA treatment. In contrast, the vanadate-induced NO production and cytotoxicity were not affected by EGTA treatment in the MC3T3E1 cells (data not shown). These results seem to indicate that the effect of high doses of vanadate could be independent of extracellular $\mathrm{Ca}^{2+}$.

\section{Discussion}

The results of our experiments demonstrate that incubation of osteoblast-like cells with vanadate leads to a biphasic concentration-dependent increase in NO formation. This effect involved two isoforms of NOS, eNOS and iNOS, present in the osteoblasts. In addition, we partially characterized the eNOS mediated-NO production by its $\mathrm{Ca}^{2+}$ dependence.

In these studies, we used two osteoblast-like cells to investigate the mechanism by which vanadate could mediate its effects. As we previously reported (Cortizo and Etcheverry, 1995; Barrio et al., 1997; Sálice et al., 1999), vanadate induced a biphasic effect in both cell lines (Table 1): low concentrations stimulated, while high doses inhibited cell growth and differentiation. In addition, the nontransformed MC3T3E1 line was more sensitive to vanadate toxicity than was the osteosarcoma UMR106 cell line. Cells of the latter cell line express high levels of alkaline phosphatase activity and have a more differentiated osteoblast phenotype. In contrast, MC3T3E1 cells produce low or undetectable amounts of alkaline phosphatase, but they synthesize collagen type I (Sudo et al., 1983).

The effects of vanadate on cell growth were in parallel with the release of NO (Fig. 1). In our cultures, the basal production of $\mathrm{NO}$ by both osteoblastic cells was similar and in the order of $1 \mu \mathrm{M}$ or $10 \mathrm{nmol} / \mathrm{mg}$ protein. This low level of NO is in the range previously reported by other authors in osteoblastic cells (Van't Hof and Ralston, 1997; Hikiji et al., 1997; Damoulis and Hauschka, 1997). However, high concentrations of vanadate $(>50 \mu \mathrm{M})$ significantly enhanced NO secretion. This response was more pronounced in the MC3T3E1 cells (Fig. 1). To our knowledge, this is the first report showing a direct effect of vanadate on NO production by osteoblast-like cells. Only two reports have suggested that vanadate could mediate its effect by the NO pathway. For instance, Nakaike et al.(1996) showed that the vanadate-induced relaxation of endothelium was abolished by $N^{\omega}$-nitro-L-arginine methylester and pertussis toxin, although they did not measure NO production or the expression of eNOS. However, their 
results could indicate that the NO pathway is involved in the effects of vanadate. In addition, in bone marrow-derived macrophages, Shishodia et al. (1997) showed that pre-treatment with $10 \mu \mathrm{M}$ vanadate enhanced cytokine-induced NO production and cytotoxicity. In our osteoblast cultures, IL-1 plus LPS stimulated NO production (data not shown); however, this effect was not enhanced by the addition of $50 \mu \mathrm{M}$ vanadate (unpublished results). Thus, our results suggest that the bioactivity of vanadate on osteoblasts could be mediated by the NO released in the medium.

This hypothesis is also supported by the results obtained by using the NO donor, sodium nitropruside (Fig. 2A). This agent slightly stimulated UMR106 proliferation; however, high concentrations were cytotoxic to the osteoblastlike cells. In addition, sodium nitropruside was a strong inhibitor of osteoblast differentiation (Fig. 2B). The effect of NO donors on osteoblast growth has been previously shown, although the results for osteoblast differentiation are controversial. Damoulis and Hauschka (1997), using MC3T3E1 osteoblasts, demonstrated the cytotoxic effect of sodium nitropruside. Danziger et al. (1997) also showed that the NO-releasing agent 3-morpholino sydnonimine (SIN-1) inhibited human primary cultures of osteoblasts in a concentration-dependent manner: the effect was detected at 1 and $10 \mu \mathrm{M}$ SIN-1. Moreover, they demonstrated that cultures exposed to SIN-1 also displayed a decreased production of both alkaline phosphatase and osteocalcin. In contrast, Hikiji et al. (1997) found that low concentrations of sodium nitropruside $\left(10^{-8} \mathrm{M}\right)$ for $5 \mathrm{~h}$ dose-dependently elevated alkaline phosphatase in primary cultures of mouse osteoblasts. They suggest that NO directly facilitates osteoblast differentiation. The different results could be due to a different experimental protocol or a different sensitivity of the osteoblastic cells used. In contrast, our results confirm the previous observation that exogenous NO is cytotoxic to osteoblasts and can mimic the effect of vanadate.

In order to further investigate the role of the NO pathway in the effect of vanadate, we tried to characterize the NOS involved in its effects. Previous observations revealed that two major isoforms of NOS are expressed in osteoblastic cells, namely, eNOS and iNOS. The endothelial constitutive NOS is expressed in osteoblasts and can be upregulated by estrogen (Armour and Ralston, 1998). eNOS was also detected by Western blot in MC3T3E1 cells (Fig. 3A) and its expression was enhanced by low concentrations of vanadate $(>10 \mu \mathrm{M}$; Fig. 3B). Low expression of iNOS was also detected in osteoblasts under basal conditions, and this expression was stimulated by high concentrations of vanadate (over $75 \mu \mathrm{M}$ ). These observations suggest that the two isoforms of NOS are involved in the NO-release induced by vanadate in osteoblast-like cells.

In addition, vanadate-induced $\mathrm{NO}$ production was partially inhibited by the $\mathrm{Ca}^{2+}$ chelator EGTA (Table 3). This effect was abolished by increasing the vanadate concentration, suggesting that a $\mathrm{Ca}^{2+}$-independent mechanism is also involved. Moreover, NO formation was increased in osteoblastic cells in the presence of the $\mathrm{Ca}^{2+}$ ionophore A23187 (Table 2). This ionophore also enhanced the vanadate-induced NO content after a 24-h incubation. Altogether, our results suggest that $\mathrm{Ca}^{2+}$-dependent and -independent mechanisms participate in vanadate-induced NO production, involving eNOS and iNOS isoforms.

In summary, vanadate induced NO production in a biphasic dose-dependent manner. The NOS responsible appeared to be both a $\mathrm{Ca}^{2+}$-dependent eNOS and a $\mathrm{Ca}^{2+}$ independent iNOS. High levels of either endogenous or exogenous NO seem to be cytotoxic to osteoblasts. In addition, the expression of eNOS induced by low concentrations of vanadate could play a role in the mitogenic effects of vanadate on osteoblast growth.

\section{Acknowledgements}

SBE is a member of the Carrera del Investigador, CONICET, Argentina and AMC is a member of the Carrera del Investigador, CICPBA, Argentina. This work was supported by grants from Facultad de Ciencias Exactas, UNLP; CICPBA; the Agencia de Promoción Científica y Tecnológica (PICT 00375) and CONICET (PIP 1044/98).

\section{References}

Armour, K.E., Ralston, S.H., 1998. Estrogen upregulates endothelial constitutive nitric oxide synthase expression in human osteoblast-like cells. Endocrinology 139, 799-802.

Barrio, D.A., Braziunas, M.D., Etcheverry, S.B., Cortizo, A.M., 1997. Maltol complexes of vanadium(IV) and (V) regulate the alkaline phosphatase activity and the osteoblast-like cell growth. J. Trace Elem. Med. Biol. 11, 110-115.

Bradford, M., 1976. Rapid and sensitive method for quantitation of microgram quantities of protein utilizing the principle of protein-dye binding. Anal. Biochem. 72, 248-254.

Chae, H.J., Park, R.K., Chung, H.T., Kang, J.S., Kim, M.S., Choi, D.Y., Bang, B.G., Kim, H.R., 1997. Nitric oxide is a regulator of bone remodelling. J. Pharm. Pharmacol. 49, 897-902.

Cohen, N., Halberstam, M., Shlimovich, P., Chang, C.J., Shamoon, H., Rossetti, L., 1995. Oral vanadyl sulfate improves hepatic and peripheral sensitivity in patients with non-insulin-dependent diabetes mellitus. J. Clin. Invest. 95, 2501-2509.

Cortizo, A.M., Etcheverry, S.B., 1995. Vanadium derivatives act as growth factor-mimetic compounds upon differentiation and proliferation of osteoblast-like UMR106 cells. Mol. Cell. Biochem. 145, 97-102.

Cusi, K., Cukier, S., Defronzo, R., Torres, M., 1997. Metabolic effects of treatment with vanadyl sulfate in NIDDM. Diabetes 46 (1), 34A.

Damoulis, P.D., Hauschka, P.V., 1997. Nitric oxide act in conjunction with proinflammatory cytokines to promote cell death in osteoblasts. J. Bone Miner. Res. 12, 412-422.

Danziger, R.S., Zuckerbraum, B.S., Pensler, J.M., 1997. Role of nitric oxide in the regulation of osteoblast metabolism. Plast. Reconstr. Surg. 100, 670-673.

Docena, G.H., Benítez, P., Campos, R.E., Macia, A., Fernández, R., 
Fossati, C.A., 1999. Detection of allergens in Aedes albifasciatus mosquito (Diptera: Culicidae) extracts by immunological methods. Invest. Allergol. Clin. Immunol. 9, 165-171.

Domingo, J.L., 1996. Vanadium: a review of the reproductive and developmental toxicity. Reprod. Toxicol. 10, 175-182.

Etcheverry, S.B., Cortizo, A.M., 1998. Bioactivity of vanadium compounds on cells in culture. In: Nriagu, J.O. (Ed.), Vanadium in the Environment. Wiley, New York, pp. 359-394.

Etcheverry, S.B., Crans, D.C., Keramidas, A.D., Cortizo, A.M., 1997. Insulin-mimetic action of vanadium compounds on osteoblast-like cells in culture. Arch. Biochem. Biophys. 338, 7-14.

Fox, S.W., Chow, J.W.M., 1998. Nitric oxide synthase expression in bone cells. Bone 23, 1-6.

Goldfine, A.B., Simonson, D.C., Folli, F., Patti, M.E., Kahn, C.R., 1995. Metabolic effects of sodium metavanadate in humans with insulin-dependent and noninsulin-dependent diabetes mellitus in vivo and in vitro studies. J. Clin. Endocrinol. Metab. 80, 3311-3320.

Green, L.C., Wagner, D.A., 1982. Analysis of nitrate, nitrite, and (15N)nitrate in biological fluids. Anal. Biochem. 126, 131-138.

Gresser, M.J., Tracey, A.S., 1990. Vanadate as phosphate analogs in biochemistry. In: Chasteen, N.D. (Ed.), Vanadium in Biological Systems. Kluwer Academic Publishing, Netherlands, pp. 63-79.

Halberstam, M., Cohen, H., Shlimovich, P., Rossetti, L., Shamoon, H., 1996. Oral vanadyl sulfate improves insulin sensitivity in NIDDM but not in obese nondiabetic subjects. Diabetes 45, 659-666.

Helfrich, M.H., Evans, D.E., Grabowski, P.S., Pollock, J.S., Ohshima, H., Ralston, S.H., 1997. Expression of nitric oxide synthase isoforms in bone and bone cell cultures. J. Bone Miner. Res. 12, 1108-1115.

Hikiji, H., Shin, W.S., Oida, S., Takato, T., Koizumi, T., Toyo-oka, T., 1997. Direct action of nitric oxide on osteoblastic differentiation. FEBS Lett. 410, 238-242.

Hukkanen, M.V., Platts, L.A.M., Fernandez de Marticorena, I., O’Shaughnessy, M., Macintyre, I., Polak, J.M., 1999. Developmental regulation of nitric oxide synthase expression in rat skeletal bone. J. Bone Miner. Res. 14, 868-877.

Laemmli, E.K., 1970. Cleavage of structural protein during the assembly of the head of bacteriophage T4. Nature 227, 680-685.

Lowry, O.H., Rosebrough, N.J., Farr, A.J., Randall, R.J., 1951. Protein measurement with Folin phenol reagent. J. Biol. Chem. 193, 265-275.

McCarthy, I.D., Andhoga, M., Batten, J.J., Mathie, R.T., 1997. Endothelium-dependent vasodilatation produced by the L-arginine/nitric oxide pathway in normal and ischemic bone. Acta Orthop. Scand. 68, 361-368.

Nakaike, R., Shimokawa, H., Owada, M.K., Tokunaga, O., Yasutake, H., Kishimoto, T., Imada, C., Shiraishi, T., Egashira, K., Takeshita, A.,
1996. Vanadate causes synthesis of endothelium-derived NO via pertussis toxin-sensitive $\mathrm{G}$ protein in pigs. Am. J. Physiol. 271, $\mathrm{H} 296-\mathrm{H} 302$

Nriagu, J.O., 1998. History, occurrence, and uses of vanadium. In: Nriagu, J.O. (Ed.), Vanadium in the Environment. Wiley, New York, pp. $1-24$

Okajima, T., Nakamura, K., Zhang, H., Ling, N., Tanabe, T., Yasuda, T., Rosenfeld, R.G., 1992. Sensitive colorimetric bioassay for insulin-like growth factor (IGF) stimulation of cell proliferation and glucose consumption: Use in studies of IGF analogs. Endocrinology 130, 2201-2212.

Ralston, S.H., 1997. Nitric oxide and bone: what a gas! Br. J. Rheumatol. $36,831-838$

Ralston, S.H., Todd, D., Helfrich, M., Benjamin, N., Grabowski, P.S., 1994. Human osteoblast-like cells produce nitric oxide and express inducible nitric oxide synthase. Endocrinology 135, 330-336.

Sabbioni, E., Pozzi, G., Devos, S., Pintar, A., Casella, L., Fischbach, M., 1993. The intensity of vanadium(V)-induced biotoxicity and morphological transformation in BALB/3T3 cells independent on gluthatione-mediated biorreduction to vanadium(IV). Carcinogenesis 14, $2565-2568$.

Sálice, V.C., Cortizo, A.M., Gómez Dumm, C.L., Etcheverry, S.B., 1999. Tyrosine phosphorylation and morphological transformation induced by four vanadium compounds on MC3T3E1 cells. Mol. Cell. Biochem. 198, 119-128.

Shechter, Y., 1990. Insulin-mimetic effect of vanadate. Possible implications for future treatment of diabetes. Diabetes 39, 1-5.

Shishodia, S., Sodhi, A., Shrivastava, A., 1997. Cisplatin-induced activation of murine bone marrow-derived macrophages require protein tyrosine phosphorylation. Int. J. Immunopharmacol. 19, 683-690.

Stein, G.S., Lian, J.B., 1993. Molecular mechanism mediating proliferation/differentiation interrelationships during progressive development of the osteoblast phenotype. Endocr. Rev. 14, 424-442.

Sudo, H., Kodama, H.A., Amagai, Y., Yamamoto, S., Kasai, S., 1983. In vitro differentiation and calcification in a new clonal osteogenic cell line derived from newborn mouse calvaria. J. Cell Biol. 96, 191-198.

Togari, A., Arai, M., Mogi, M., Kondo, A., Nagatsu, T., 1998. Coexpression of GTP cyclohydrolase I and inducible nitric oxide synthase mRNAs in mouse osteoblastic cells activated by proinflammatory cytokines. FEBS Lett. 428, 212-216.

Van't Hof, R.J., Ralston, S.H., 1997. Cytokine-induced nitric oxide inhibits bone resorption by inducing apoptosis of osteoclast progenitors and suppressing osteoclast activity. J. Bone Miner. Res. 12, $1797-1804$. 